\title{
Kaukių baliai ir XVIII a. visuomenè
}

Lina Balaišytè

Lietuvos kultūros tyrimų institutas

Saltoniškių g. 58, LT-08105 Vilnius

1.balaisyte@gmail.com

Kaukiu baliai, arba maskaradai, XVIII a. tapo populiariu miesto renginiu. Tai buvo unikali pramoga, kurioje galejjo linksmintis kartu skirtingi luomai. Straipsnyje kaukių baliai tiriami kaip socialinis reiškinys. Aptariama XVIII a. visuomenės sankloda ir joje vykę pokyčiai, lėmę luomų ribas niveluojančios pramogos poreiki, bei jos refleksija.

Reikšminiai žodžiai: XVIII a. visuomenè, kaukių baliai (maskaradai), luomai. 
Kaukių baliai paplito Europos miestuose XVIII a. kaip viešas renginys, ị kurị žmonės galèjo patekti nusipirkę bilietą ir dėvėdami kaukes. Toks pasilinksminimas tapo prieinamas visiems gyventojų sluoksniams ir sukūrè galimybę linksmintis drauge didikams, bajorams ir miestiečiams, kas buvo neįmanoma kitomis aplinkybėmis griežtai stratifikuotoje visuomenėje. Abiejų Tautų Respublikoje (toliau - ATR) kaukių baliai paplito XVIII a. pirmoje pusėje. Manoma, kad juos išpopuliarino Augustas II, pats mėgęs ir noriai dalyvavęs Varšuvos maskaraduose'. Vilniuje kaukių baliai pradèti rengti XVIII a. antroje pusėje. Iš pradžių tai buvo viena iš karnavalo laikotarpio pramogų, rengtų nuo Trijų karalių šventès iki Pelenų trečiadienio (šaltiniuose lenkiškai vadinamu Zapusty arba Karnawat), tačiau vėliau maskaradai populiarėjo, o jų rengimo laikas ilgèjo. Jie nebebuvo susiję tik su Užgavėnių linksmybėmis, o tapo komerciniu renginiu ir išskirtine miesto pramoga.

Kaukių baliai, kaip specifinis XVIII a. reiškinys, buvo tirti papročių istorijos, socialinės tapatybės, moteru istorijos kontekste, daug tyrèju dėmesio sulaukè maskaradų vaizdinys grožinėje literatūroje $e^{2}$. Literatūrinè šio reiškinio refleksija tirta ir XVIII a. maskaradams ATR skirtose studijose. Jie buvo aptariami tarp kitų karnavalo pramogu ir teatralizuotų diduomenès pasilinksminimų ${ }^{3}$ Buvo tirti ir kaukių balių aprašymai amžininkų atsiminimuose $e^{4}$ Apie XVIII a. Vilniaus maskaradus rašyta tik trumpame, tačiau sodriame iž̌valgomis ir faktais Liudo Glemžos tekste, paskelbtame internetiniame portale ${ }^{5}$. Šiuo metu rengiamas publikacijai Redos Griškai-

1 Antonis Magieras (1762-1837) 1833 m. išleistuose atsiminimuose Estetyka miasta stolecznego Warszawy rašè: „Pirmieji kaukių baliai Varšuvoje buvo rengiami Piekarska gatvès name, turbūt dèl jų erdvumo. Juose valdovas [Augustas II] būdavo iki vėlyvos nakties“; Ewa Nofikow, Polski karnawat: obrazy obyczajów świątecznych w piśmiennictwie trzech stuleci: od XVII do XIX wieku, Białystok: Wydawnictwo Uniwersytetu w Białymstoku, 2015, p. 88.

2 Dalyko bibliografija pateikiama: Terry Castle, Masquerade and Civilization.

The Carniwalesque in Eighteenth-Century English Culture and Fiction, Stanford: Stanford University Press, 1986; Paweł T. Dobrowolski, Poszukiwanie tożsamości: cztery studia o angielskim Oświeceniu, Warszawa: Collegium Civitas Press, 2015.

3 Janusz Ryba, Maskarady oświeconych. Próba opisu zjawiska, Katowice: Wydawnictwo Uniwersytetu Śląskiego, 1998; Idem, Oświeceniowe tutti frutti. Maskarady-konwersacja-literatura, Katowice: Wydawnictwo Uniwersytetu Śląskiego, 2009; Ewa Nofikow, op. cit.

4 Tomasz Ciesielski, „Zapusty szlacheckie i magnackie w XVIII wieku w świetle Opisu obyczajów za panowania Augusta III Jędzieja Kitowicza oraz pamiętników i dzienników z czasów saskich“, in: Memuarystyka w dawnej Polsce, redakcja Piotr Borek, Dariusz Chemperek, Anna Nowicka-Struska, Kraków: Collegium Columbinum, 2016, p. 203-217.

5 Liudas Glemža, „Vilniaus pramogos: maskaradai“, [interaktyvus], [žiūrèta 2019-04-30], http://m.ldkistorija.lt/index.php/istoriniai-faktai/pramogos-vilniuje-maskaradai/1326. 
tès tekstas, skirtas XIX a. Vilniaus pasilinksminimams, kuriame skelbiama daug žinių apie kaukių balius iš amžininkų atsiminimų ${ }^{6}$.

Kalbėdami apie šaltinius, galime pastebėti, kad kaukių balių aprašymai XVIII a. egodokumentuose buvo gana lakoniški, skirtingai negu vėlesnio amžiaus atsiminimuose, kupinuose detalių ir asmeninių refleksijų. Šị klausimą tyręs Tomaszas Ciesielskis spejja, kad XVIII a. aukštuomenès rašytuose dienoraščiuose ir atsiminimuose net išskirtiniai kaukių baliai neminimi, nes jie buvo skirti siauresniam šeimos ir klientų ratui ${ }^{7}$. Kaukių balių aprašymų sunku rasti ir Lietuvos Didžiosios Kunigaikštystės diduomenès korespondencijoje ${ }^{8}$. Išsamiausią ir vaizdžiausią kaukių balių aprašymą paliko Augusto III laikų papročių metraštininkas Jędrzejus Kitowiczius ${ }^{9}$. Tam tikrų detalių apie maskaradų eiga galime rasti ir grožinėje to meto literatūroje, konkrečiau - poezijoje , apie kaukių balius pranešdavo ir to meto spauda. Šiame straipsnyje siekiama, pasitelkus minėtus rašytinius šaltinius, ištirti, kaip kaukių baliai funkcionavo XVIII a. visuomenėje, kokia buvo ju reikšmė ir refleksija.

\section{Maskaradai XVIII amžiuje}

Kaukių balių atsiradimas siejamas su Venecijos festa tradicija. Edukacinės užsienio kelionès lèmè spartų šio švenčių modelio paplitimą visoje Europoje ${ }^{11}$. XVIII a. pradžioje maskaradai imti rengti Europos mies-

6 Reda Griškaitè, „Šokantis Vilnius“, atiduotas spaudai, in: Pasakojimai apie Vilniu ir vilniečius III, Vilnius: Lietuvos istorijos institutas, 2020. Nuoširdžiai dèkoju autorei už galimybę pasinaudoti straipsnio rankraščiu.

7 Tomasz Ciesielski, op. cit., p. 205. Tą pati pastebẻjo ir Ewa Nofikow, rašydama apie XVII a. kaukių balius: „Iddomu, kad XVII a. miestiečių ir bajorų atsiminimuose ir dienoraščiuose dažnai nėra nė menkiausios užuominos apie karnavalus arba rašyta labai lakoniškai. Kaukių dèvėjimas buvo karnavalo kasdienybė, tam neskirta daug dėmesio, apsiribojant pasakymais. Buvo šokiai ir kaukès““; Ewa Nofikow, op. cit., p. 36-37.

8 Štai Domininko Burbos straipsnyje aptariamoje Jono Dominyko Lopacinskio korespondencijoje karnavalo laikotarpis minimas tik gatvės linksmybių ir vedybų meto kontekste, dar karnavalo ir kaukės motyvas vartojamas su neigiama konotacija, kalbant apie politini krašto gyvenimą. Žr. Domininkas Burba, „Bajorų gyvenimo peripetijos XVIII a. vidurio Lietuvos Didžiosios Kunigaikštystės sostinejje pagal Vilniaus kanauninko Jono Dominyko Lopacinskio asmeninę korespondenciją“, in: Istorija, 2015, t. 97, Nr. 1, p. 26-46.

9 Jędrzej Kitowicz, Opis obyczajów za panowania Augusta III, Warszawa: Państwowy Instytut Wydawniczy, 1999.

10 Keli kaukių baliams skirti eilèraščiai paskelbti: Wiersze polityczne Pierwszego rozbioru i Sejmu delegacyjnego, 1772-1775, opracowała Barbara Wolska, Warszawa: Wydawnictwo Sejmowe, 2001.

11 Terry Castle, op. cit., p. 12. 
tuose kaip vieši pasilinksminimai. Pavyzdžiui, Paryžiuje 1716 m. pradèti rengti bals de l'Opéra, vieši renginiai, kurie perkèlè kultūrinị centrą iš dvaro (Versalio) ì miesto aplinką. Skirtingai negu dvaro pasilinksminimai, šie neturèjo šeimininko, o įejjimo mokestis, nors didelis, nebuvo kliūtis patekti i juos tiems, kas negalėdavo dalyvauti dvaro šventėse dėl kilmės. I Paryžiaus balius susirinkdavo šimtai ir net tūkstančiai asmenų ${ }^{12}$. Londone $1713 \mathrm{~m}$. pirmą kaukių balių surengė Prancūzijos ambasadorius savo rezidencijoje ir užkrètė šiuo pasilinksminimu britus ${ }^{13}$. Spartų maskaradų populiarėjimą Londone rodė laikraščiuose reguliariai spausdinami jų skelbimai. Antroje amžiaus pusėje laikraščiuose atsirado atskira skiltis, kurioje buvo aprašomi išskirtiniai kaukių baliai ${ }^{14}$. Terry Castle pastebi, kad XVIII a. londoniečiams maskaradai su jų erotiška, maištinga ir paslaptinga dvasia, buvo nemažiau ìdomūs nei aktualūs politiniai ịvykiai ${ }^{15}$.

XVIII a. kaukių baliai turejo sąsajų su senosiomis karnavalo tradicijomis. Klasikiniai maskaradų bruožai - slèpimasis po kauke, persirengimas, žodinis ir fizinis laisvumas - buvo tradiciniai karnavalo elementai, susiję su tokiais fenomenais, kaip senovės romėnų Saturnalijos, viduramžiais vykusios karnavalinės eisenos ${ }^{16}$. Tačiau maskaradai skyrèsi nuo kitų karnavalo linksmybių, nes turèjo komercinị pobūdị ir buvo sekuliarūs renginiai. Juose tvyrojo teatrališkumo dvasia, tačiau kaukių baliai paprastai neturèjo jokios programos ${ }^{17}$. Klasikinès karnavalų šventės vykdavo atvirame ore, miesto gatvėse, o XVIII a. maskaradai, priešingai, buvo atskirti nuo gatvès - vyko uždarose patalpose, neretai kuriant išskirtinumo i̦spūdį ${ }^{18}$. Pawełas T. Dobrowolskis pastebejjo, kad toks buvo kaukių balių paradoksas: maskaradai buvo reklamuojami kaip aukštuomenę sutraukiantys pasilinksminimai, tačiau tarp pasaulietinių institutų išsiskyrè būtent tuo, kad juose realiai maišèsi luomai ${ }^{19}$.

12 Paweł T. Dobrowolski, op. cit., p. 45.

13 Ibid., p. 47.

14 Terry Castle, op. cit., p. 3.

15 Ibid.

16 Ibid., p. 11.

17 Ibid., p. 20.

18 Pvz., Londone maskaradų rengėjai dèl komercinės sėkmės siekė sudaryti prabangos ir elitiškumo ịspūdį, nors bilietų kainos nebuvo labai didelès. Žr. Paweł T. Dobrowolski, op. cit., p. 35, 37. 19 Ibid., p. 38. 
ATR kaukių baliu tradicija buvo sena, tačiau ilgą laiką tai buvo aukštuomenės pramoga ${ }^{20}$. Kaukių baliai tebebuvo aktyviai rengiami didiku dvaruose ir XVIII amžiuje. Štai Mykolas Ksaveras Sapiega dienoraštyje mini $1752 \mathrm{~m}$. padieniui dvare rengtus maskaradus ${ }^{21}$. Iprasti karnavalinio meto pokyliai su maskaradais buvo ir Radvilų dvaruose ${ }^{22}$. Tačiau vieši kaukių baliai, lenkiškai vadinti redutais, kaip buvo minèta, buvo naujas, tik XVIII a. atsiradęs reiškinys. Kitowiczius, rašydamas apie Augusto III laiku papročius, kiek pavèlina redutu atsiradimo ATR datą, nei anksčiau minètoji: jo teigimu, redutai atsirado Varšuvoje Augusto III valdymo viduryje, matyt, 4 ar 5 dešimtmetyje. Anot jo, iš pradžiu jie buvo rengiami vienoje vietoje nuo Naujujų metų iki Pelenų dienos dukart per savaitę: antradienị ir ketvirtadienį. Keliolika metų juos rengė vienas asmuo - italų kilmės Varšuvos gyventojas Salvadoras. Augusto III valdymo pabaigoje redutai pritraukdavo vis daugiau žmonių ir jie pradèti rengti keliose vietose, be to, vykdavo ilgesni laikotarpị: šešias savaites prieš adventą ir šešias prieš gavènią, jau penkias dienas per savaitę nuo sekmadienio iki ketvirtadienio. Anot Kitowicziaus, greitai kaukių baliai pradèti rengti ir kituose miestuose, taip pat ir Vilniuje ${ }^{23}$.

Apie Vilniuje rengtus kaukių balius laikraščiai pranešdavo nuo XVIII a. 8 deš., tačiau nèra žinoma, ar jie organizuoti reguliariai. Liudas Glemža aprašè vèlesnio dešimtmečio redutu rengimo Vilniuje peripetijas, kurios siejosi su Franciszeko Ryxo asmeniu. Šis valdovui artimas žmogus iš pradžiu išsirūpino monopolinę teisę visiems reginiams, mokamoms viešoms pramogoms ir redutams Varšuvoje, tuomet sumanė išplėsti savo veiklą ị Vilnių ${ }^{24} .1780$ m. Vilniaus magistratas sudarė su Ryxu sutartí, pagal kurią jis vienintelis galëjo mieste rengti maskaradus ir laikyti kavines. Jam

20 Išliko žinių apie XVII a. valdovo dvaruose rengtus Užgavėnių šventimus. Bene pirmas aprašytas karnavalinis vaidinimas Lietuvoje įvyko $1644 \mathrm{~m}$. sausio 20 d. Vilniaus žemutinėje pilyje. Žr. Liudas Glemža, op. cit.

21 Sapiega rašo, kad Slanime $1752 \mathrm{~m}$. vasario $13 \mathrm{~d}$. surengtas kaukių balius, vasario $14 \mathrm{~d}$. „balius su kaukèmis“, vasario 15 d. - „balius, gausiai dalyvaujant kaukėms“. Žr. Tomasz Ciesielski, op. cit., p. 205-206.

22 Ibid., p. 207.

23 Jędrzej Kitowicz, op. cit., p. 300-304.

24 Franciszekas Ryxas buvo spalvinga asmenybè: kilęs iš Flandrijos ir savo karjerą Respublikoje pradėjęs kaip LDK pakanclerio Mykolo Antano Sapiegos kirpėjas, vèliau Ryxas tapo valdovo Stanislovo Augusto kamerdineriu, $1768 \mathrm{~m}$. buvo nobilituotas, igijo karaliaus dvaro šambeliono titulą ir praktiškai tvarkė karaliaus asmeninị iždą. Žr. Karyna Wierzbicka-Michalska, Jerzy Michalski, „Ryx Franciszek“, in: Polski Stownik Biograficzny, Wrocław, Warszawa, Kraków: Zakład Narodowy Imienia Ossolińskich, Wydawnictwo PAN, 1991-1992, t. 33, p. 597-601. 
buvo nurodyta atidaryti ir viešaji miesto teatrą 25 . Tačiau gavęs monopolines teises, Ryxas nesirūpino nei teatro atidarymu, nei loterijų bei kaukių balių rengimu, dèl ko nuolat skundèsi vilniečiai ${ }^{26}$. 1792 m. magistratas kreipèsi i Policijos komisiją ir pranešè, kad mieste atsirado keletas asmenų, kurie sutiktų rengti kaukių balius. Magistratas kiek nuogąstavo dèl per didelio pasilinksminimų vietų skaičiaus, kuris, matyt, galëjo kelti grèsmę miestiečiu moralei: „keletas tokių vietų amatininkams, tarnams ir kitiems žmonèms gali labiau pakenkti, nei atnešti naudos“"27. Tačiau galų gale maskaradus buvo leista rengti su sąlyga, kad jų organizatoriai mokès 83 raudonųjų auksinų mokesti i miesto kasą, informuos apie savo veiklą miesto ir valstybès pareigūnus, nedidins nustatytų bilietų kainų, netriukšmaus ir bažnytinių švenčių dienomis nekels linksmybių. Maskaradų rengimo teisė Vilniuje buvo suteikta trims asmenims, tarp kurių buvo ir Vilniaus pirklys Jonas Mileris (Jan Miller, Muller). Jo rengiamos loterijos ir kaukių baliai vyko išnuomotuose LDK kanclerio Aleksandro Sapiegos rūmuose Antakalnyje ${ }^{28}$. Vilniaus miestiečiui Jonui Darevskiui buvo suteikta teisė Tyzenhauzų rūmuose Vokiečių g. rengti mažuosius maskaradus, ị kuriuos buvo nustatyta iejjimo bilieto kaina - 1 auksinas, dvigubai mažesnè negu Milerio rengtuose kaukių baliuose ${ }^{29}$. Maskaradai ir XIX a. tebebuvo populiariausias karnavalinio sezono renginys Vilniuje ${ }^{30}$, skirtingai negu, pavyzdžiui, Londone, kur viešų kaukių balių populiarumas užgeso, baigiantis XVIII amžiui ${ }^{31}$.

Kitowiczius rašè, kad redutuose „pramoga buvo trejopa: šokis, žaidimas kortomis ir vienas kito apžiūrinėjimas“32. Renginyje nemokami buvo tik „šviesa ir kapela“, už kitką reikèjo brangiai mokèti, pavyzdžiui, vandens

25 Liudas Glemža, op. cit.

26 Po vilniečių skundų $1790 \mathrm{~m}$. asesorių teismas Ryxui paliko išskirtinę teisę rengti loterijas ir kaukių balius, laikyti kavines ir dar kartą nurodė per metus atidaryti teatrą. Tuomet Ryxas kaukių balių organizavimo teises neoficialiai už dideli mokestị perleido Vilniaus pirkliui Jonui Mileriui. 1791-1792 m. skundai dèl Ryxo neveiklumo nenutilo, be to, atsirado daugiau norinčių rengti viešuosius renginius Lietuvos sostinèje. Žr. Liudas Glemža, op. cit.

27 Liudas Glemža, op. cit.

28 Mileris nuolat kèlè bilietų kainas, juos pardavinėjo už 3 auksinus, nors magistrato buvo nustatyta 2 auksinų bilieto vertè, dèl to sulaukè ne tik miesto valdžios įspejjimų, bet ir piniginių baudų. Žr. Eduardas Brusokas, Liudas Glemža, ,Vilniaus savivaldos struktūra ir organizacija po ketverių metų seimo miestų reformos (1792, 1794 m.)“, in: Lietuvos istorijos metraštis, 2008, t. 1, 2009 , p. 54 .

29 Liudas Glemža, op. cit.

30 Reda Griškaitè, op. cit.

31 Terry Castle, op. cit., p. 3.

32 Jędrzej Kitowicz, op. cit., p. 301 
stiklinė kainavo 12 grašių 33 . Bet tai nesumenkino redutu populiarumo. Anot Kitowicziaus, populiarumą lèmè materialiniai dalykai:

Žmonės skaičiavo - nežinau, teisingai ar klaidingai, - kad mažiau kainuoja Užgavėnès, leidžiant jas mieste redutuose su žmonomis ir dukromis, negu kaime, kur reikėdavo priimti kompaniją su tarnais ir arkliais, juos visus maitinti, apgyvendinti ir gerti, kartais aukojant sveikatą. ${ }^{34}$

Tačiau abejotina, kad kaukių baliai traukdavo žmones galimybe pigiau pasilinksminti. Juose mielai rinkdavosi ne tik iš dvarų i miestą atvykusi bajorija, bet ir miestietija. Akivaizdu, kad buvo kažkas kito, kas sutraukdavo minias į šią pramogą ir kas skatino aukštuomenę išeiti iš siauros savo dvaro ir klientūros aplinkos. Veikiausiai labiausiai žmones masinantis dalykas buvo unikali galimybè peržengti ịprastos aplinkos ribas ir pasislèpus po kauke elgtis taip, kaip nederèjo jų luomui, lyčiai ir statusui. Kaukè buvo būdas paslèpti tapatybę ir kartu būdas naudotis neribota laisve.

Kaukių baliuose paprastai nebuvo paisoma îprastos socialinès tvarkos, pavyzdžiui, jie buvo vienintelè vieta, išskyrus bažnyčią, kur moterims buvo leidžiama ateiti be priežiūros ${ }^{35}$. Patraukli buvo ir erotiška kaukių balių atmosfera. Paslèpus veidą, labiau akcentuotas kūnas, o kostiumo kuriamas atsiskyrimas nuo tikrojo identiteto vedè prie tradicinès moralès nepaisymo ${ }^{36}$. Apie kaukių balius rašę žmonès visada pažymėdavo dideles spūstis juose ${ }^{37}$, o tai lèmè didesnę kūniško kontakto galimybę, kuri nebuvo toleruojama kitomis aplinkybemis. Europos miestuose maskaraduose dažnai dalyvaudavo ir prostitutès, kas dar labiau stiprino erotinę renginio atmosferą ${ }^{38}$. Iš Mintaujos atvykęs literatas ir istorijos profesorius Friedrichas Schulzas mini, kad ir Varšuvos redutuose gausiai dalyvaudavo gatvès merginos (dziewczęta uliczne) $)^{39}$.

\section{Ibid.}

34 Ibid., p. 303.

35 Terry Castle, op. cit., p. 32.

36 Ibid.

37 Pvz., Tomaszo Kajetano Węgierskio eilèraštyje „Ostatni wtorek“, skirtame redutams, refrenu kartojamas šūksnis: „Co za ścisk!“, „Co za tłok!“ (Kokia spūstis! Kokia kamšatis!); Tomasz Kajetan Węgierski, „Ostatni Wtorek“, [interaktyvus], [žiūrèta 2019-10-25], https://pl.wikisource.org/ wiki/Poezye_Tomasza_Kajetana_W\%C4\%99gierskiego/Ostatni_Wtorek

38 Terry Castle, op. cit., p. 32.

39 Fryderyk Schulz, Podróże Inflantczyka z Rygi do Warszawy i po Polsce w latach 1791-1793, Warszawa: Spółdzielnia Wydawnicza Czytelnik, 1956, p. 184-185. 
Kitowiczius taip pat aprašè amoralias pramogas Varšuvos kaukiụ baliuose, bet kaip ,vieninteli dalyką, kuri galètumėm pavadinti blogu ir netinkamu“"40. Jis rašè, kad kaukių baliuose be viešų salių ir kambarių, atvirų visai draugijai, antrepreneriai laike atskirus kambarius su savais raktais. „Kaukètas kavalierius prašydavo tokio rakto, sumokėdavo už jì, tuomet palydėdavo ten damą, su kuria buvo susitaręs, ir pasilinksminęs grịždavo i draugiją“41. Kitowiczius suverčia kaltę dèl amoralumo gobšiems antrepreneriams, kurie tokius dalykus sumanė, kad gautų sau daugiau pajamų. Kituose miestuose, anot jo, „nebuvo tam vietos, vien tik Varšuvoje, kur redutams nuomoti dideli rūmai“"42. Autorius teigia, kad redutuose „,visos kitos pramogos buvo padorios“. Tačiau toliau pats aprašo kitą būdą, kaip kaukių balių dalyviai galèjo „gauti gėdingus malonumus“:

\footnotetext{
kieme priešais rūmus visą naktị stovejjo samdytos karietos. Kas norėjo pasivogti svetimą žmoną ar dukrą valandèlei, slapčia išeidavo su ja iš redutu, sėsdavo ị karietą ir važiuodavo ị kokius namus arba važinėdavo nutolusiomis gatvèmis, tuomet griždavo ị redutus atskirai ir ịsimaišydavo ị draugiją. ${ }^{43}$
}

Toks paleistuvavimas suklestejo, anot jo, Stanislovo Augusto laikais. Ciesielskis pastebi, kad pagal išlikusius atsiminimus nepavyksta patikrinti nuomonès apie dideli pasileidimą, vyraujantị kaukių baliuose, nes informacijos apie juos šiuose šaltiniuose nèra ${ }^{44}$.

Maskaradų kostiumai taip pat kūrė galimybę atsidurti už savo luomo ribų. Simptomiškas buvo $1729 \mathrm{~m}$. Londono laikraščio pranešèjo pastebėjimas, kad maskarade „visi vilki aprangą, kuri pristato jị kaip priešingą, nei jis yra“"45. Castle šią kaukių baliu ypatybę ìvardija „paradoksaliai sistemiška anarchija, discordia consors“. Anot jos, santykis tarp kostiumo ir jo dèvètojo buvo ironiškas - kunigaikštienès persirengdavo pienininkėmis, tarnai - persų karaliais, sąvadautojai - vienuoliais, jaunos merginos - husarais $^{46}$. Respublikoje rengtuose maskaraduose taip pat mieliausiai buvo

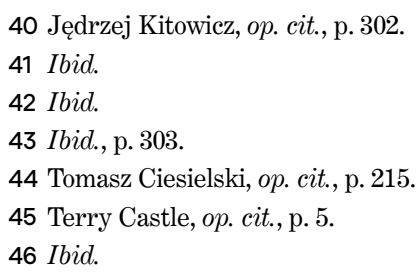


persirengiama žemesnės kilmės ar svetimų kultūrų personažais. Schulzas rašè, kad Varšuvos redutuose vyrai dažniausiai vilkėdavo sargybinių, vežèjų, vienuolių, kazokų, žydų, velnių, šikšnosparnių kostiumus, o moterys persirengdavo kaimietėmis, žydėmis, rusėnų valstietėmis, turkėmis ${ }^{47}$. Poetas Józefas Koblańskis, kaukių baliui paskyręs eilèrašti „Oda na maski krakowskie“ (Odė Krokuvos maskaradui), rašė: „Ten matomi visų amžių rūbai, mada“, tarp kaukiu paminėjo „turką, graiką, ispaną ir senovès romėną“"48. Kitas poetas Tomaszas Kajetanas Węgierskis eilèrašyje „Ostatni wtorek“ (Paskutinis antradienis) nurodè maskarade dalyvaujantị turką, husarą, ispanę, amazonę ${ }^{49}$. Kostiumams didelę ittaką darė Venecijos karnavalai, todèl pagal jų tradiciją naudotasi komedijos dell'arte personažais, taip pat neutralaus pobūdžio domino kostiumais - apsiaustais ir kaukėmis. Tokių kostiumų populiarumą vaizdžiai demonstruoja Govanni Battista Lampi tapytas Stanislovo Augusto Poniatovskio portretas, kuriame valdovas vaizduojamas vilkịs venecijietišką karnavalo kostiumą su balta kauke ${ }^{50}$. Mažiau idealizuotą požiūrị i Varšuvos pramogas išreiškęs dramaturgas ir publicistas Julianas Ursynas Nemcevičius (Julian Ursyn Niemcewicz) užsiminė ir apie vyrų lyčiai nederamus pasipuošimus. Atsiminimuose jis rašè: „Tikru pokštų ir pasileidimo teatru buvo redutai. $<\ldots>$ Visi ten dèvejjo domino arba kitokias kaukes, visi, net vyrai, parausvinti ${ }^{\text {“51. }}$.

\section{Laikai, „kai viskas slepiama po kauke”}

Januszas Ryba, tyrinėjęs XVIII a. ATR aukštuomenės gyvenimą, rašo apie Apšvietos laikais vykusią kasdienybės maskaradizacija, arba Apšvietos maskaradomanija $a^{52}$. Maskaradą jis apibrěžia plačiai - juo vadina

47 Fryderyk Schulz, op. cit., p. 185.

48 Józef Koblański, „Oda na maski krakowskie w karnawał $1774 \mathrm{w}$ bandzie

J. W. Humieneckiej, miecznikowej koronnej“, in: Wiersze polityczne Pierwszego rozbioru i Sejmu delegacyjnego, 1772-1775, opracowała Barbara Wolska, Warszawa: Wydawnictwo Sejmowe, 2001, p. 237.

49 Kajetan Tomasz Węgierski, op. cit.

$50 \mathrm{http} / /$ cyfrowe.mnw.art.pl/dmuseion/docmetadata?id=5127. Kitas pavyzdys - Stanislovo Augusto dvaro tapytojo Jano Bogumilo Plerscho turto inventoriuje minimas kaukių baliaus kostiumas: „Maskaradinis juodo šilko apsiaustas ir juoda kaukë“; Aleksandra Bernatowicz, Malarze w Warszawie czasów Stanistawa Augusta. Status, aspiracje, twórczość, Warszawa: Instytut Sztuki PAN, 2016, p. 238. M. K. Sapiega dienoraštyje mini kaukių balių, kuriame Mykolas Antanas Sapiega pasipuošè Venecijos kilmingojo kostiumu, o jo žmona vilkèjo „,yyrišką domino“. Žr. Tomasz Ciesielski, op. cit., p. 205-206.

51 Cituota iš: Ewa Nofikow, op. cit., p. 91.

52 Janusz Ryba, Maskarady oświeconych, p. 9. 
„ivairius žmogaus veiksmus, turinčius tikslą pakeisti išvaizdą ir tapatybę, apsimesti arba suklaidinti“53. Prie maskaradų Ryba priskiria XVIII a. paplitusius „maskaradiškus happeningus“, pavyzdžiui, laisvo scenarijaus Rytu karavano atvykimo vaidinimus $\mathrm{s}^{54}$, persirengimus-mistifikacijas ${ }^{55}$ ir net architektūrinius maskaradus, kaip valstiečių kaimelių imitacijas dvaruose ${ }^{56}$. XVIII a. kultūrai, anot jo, taip pat labai būdingas tapatybės slèpimas keliaujant: dažnai incognito keliauti pasirinkdavo elito atstovai, ypač valdovai ir jų šeimos nariai. Maskuojantis buvo pakeičiamas ne tik vardas, bet ir lytis, pavyzdžiui, kunigaikštienė Izabelẻ Čartoriska keliavo po Europą persirengusi pažu ${ }^{57}$.

Ryba polinkị i maskaradus aiškina tuo, kad virš Apšvietos elito tvyrojo nuovargio aura, sukelianti norą veikti netikètai, nustebinti, pasikeisti, rizikuotij ${ }^{58}$. Manyčiau, kad tai per daug supaprastintas vaizdas. Ewa Nofikow taip pat prieštaravo Rybos nuomonei, kad maskaradai galèjo „numalšinti fizinị naujumo ir kitoniškumo poreikį “"59. Toks ịsivaizdavimas atrodo pernelyg naivus. Nofikow nuomone, maskaraduose elgesio ir santykių sąlygiškumas, tuo pačiu dirbtinumas buvo aiškiai matomas. Nuostabos kategorija ir siekis nuolat nustebinti kilo būtent iš įpročiu ir stereotipų laužymo ${ }^{60}$.

Istorikai XVIII amžių ne kartą yra pavadinę „persirengimų / maskavimosi amžiumi“ (the age of disguise) ${ }^{61}$. Be abejo, turèta omenyje ne tik maskavimą veido ir kūno kauke bei kostiumu. Dobrowolskis yra pastebėjęs, kad XVIII amžius, paprastai įvardijamas Proto amžiumi, kartu buvo, kaip

53 Ibid., p. 19.

54 Prie tokių happeningu priskirtina ir valdovo sutikimo Aleksandros Oginskienès dvare Siedlcuose programa, turèjusi maskarado pobūdị: rūmų parke karalių sutiko personažai, persirengę turkais, graikais, pirkliais iš Kinijos, venecijiečiais, čigonais, baškirais. Žr. Janusz Ryba, Maskarady oświeconych, p. 31; Idem, Oświeceniowe tutti frutti, p. 41-56.

55 Ryba pateikia Adomo Kazimiero Čartoriskio atvykimo ị Varšuvą, apsimetus persu burtininku, pavyzdį. Žr. Janusz Ryba, Maskarady oświeconych, p. 41.

56 Toki kaimeli turèjo Adomas Kazimieras ir Izabelè Čartoriskiai Povonzkuose prie Varšuvos. Žr. Janusz Ryba, Oświeceniowe tutti frutti, p. 33-40.

57 Janusz Ryba, Oświeceniowe tutti frutti, p. 19-32.

58 Janusz Ryba, Maskarady oświeconych, p. 18.

59 „Persirengiama turkais, arabais, rytų turtuoliais ar plebejais, kad nors akimirkai pasiduotų îsitikinimui apie pakeistą tapatybę. < ... S Ši dekoracija suteikè galimybę patirti patrauklias keliones erdvejje ir laike: galima buvo ne tik pasijausti arabu, turku ar kinu, bet taip pat akimirkai turèti iliuziją buvimo Kinijoje, Arabijoje, Turkijoje ar Antikinėje Romoje“. Žr. Janusz Ryba, Maskarady oświeconych, p. 17

60 Ewa Nofikow, op. cit., p. 81.

61 Terry Castle, op. cit., p. 5. 
nebūtų paradoksalu, laikotarpis, kai persirengimai, tikrosios tapatybės slèpimai, mistifikacijos buvo pasiekę didžiausią mastą ${ }^{62}$. Apšvietos racionalizmo triumfas, anot jo, kartu buvo nuolatinio netikrumo laikotarpiu. Neveltui to meto grožinė literatūra buvo pilna protagonistų, kurių statusas yra neaiškus, laikomas paslaptyje arba nežinomas. Našlaičiai, pamestinukai, moterys, persirengusios vyrais, tarnai - ponais ar poniomis, kurių rizikingus nuotykius aprašo Apšvietos apsakymai ir dramos, parodo nuolatini galynèjimąsi su tapatybės problema ${ }^{63}$. Dobrowolskis pastebi, kad maskavimasis suteikė hierarchiškai visuomenės vaidmenų sanklodai ambivalentiškumo, neaiškumo ir sąmoningo žaidimo elementą ${ }^{64}$. Maskaraduose buvo akivaizdžiausiai realizuojamas polinkis kurti iliuziją ir apgaulę, kurios vieniems buvo kontroliuojamo viešo žaidimo elementas, kitiems - būdas užmaskuoti savo, dažnai žemesnę, visuomeninę padètį ${ }^{65}$.

Visuomenės, kurioje apsimetinėjama ir bandoma pasisavinti svetimą tapatybę, kritika buvo dažna sentimentalistinès literatūros tema. Pavyzdžiui, Vilniaus literatas Vincentas Ignacas Marevičius (Wincenty Ignacy Marewicz), kritikuodamas savo laiko visuomenę, rašè, kad dabar „visi slepiasi po kaukèmis“. Norėdamas parodyti gyvenimo mieste ydas, jis vaizdavo jo gyventojus, apsimetančius tuo, kuo nèra:

Pažvelkime dabar ị tas minias gatvėse. Prancūzas, jojantis ant greito žirgo, tai moteris, nedèkinga Kūrẻjui dèl jai duotų dovanų, atmetanti Jo darbą, kad ne vyru ją sutvèrè, bet moterimi, besistengiant apgauti pasauli ir išeiti iš savo lyčiai deramų ribų. Tas kitas pabalintas, parausvintas ir iškvėpintas visokiais parfumais dabita yra buduaro riteris, besivaržantis su damomis, ar jis joms, ar damos jam meilintis turi. < ...> Išvaizdą turi teatrališką, o jo jausmai, sprendimai ir ketinimai - apgaviko <...> Dabar pažiūrèk ị tą madingą karietą, kuri prie mūsų artėja. Ji turi garbę talpinti savyje tris labai svarbius žmones, kurie dèl jų vardo didybès ir titulų prašmatnumo, autoriteto, puikumo ir delikačios sveikatos nedrịsta ir trijų žingsnių pėsčiomis žengti, liepia iš gatvès ị gatvę iškilmingai pervežti. Vienas jų Lenkijoje vadinasi Baronas de Mada, prancūzų kariuomenės pulkininkas, o užsienyje buvo odininko, gerai išdirbančio avių odą vieno prancūzų pulkininko dvare, sūnus, apvo-

62 Paweł T. Dobrowolski, op. cit., p. 9.

63 Ibid., p. 43.

64 Ibid., p. 7.

65 Ibid. 
gęs tą pulkininką ir pabėgęs į Lenkiją. Kitas vadinasi Grafas de Etiketas, slaptas užsienio tarėjas, kadaise buvęs arklių felčeris pas vieną grafą, kurị nužudęs kelyje ir paėmęs pinigus atvyko į Lenkiją < ...> Žiūrèk ị tas dvi damas po žaliu lietsargiu. Ta viena, pasipūtusia mina, yra paprasta darbininkè, kuri visą savaitę sunkiai dirba ir badauja, sutaupydama po kelis grašius per dieną, kad šventadienị galètų pas kirpėją dviejų aukštų šukuoseną sukelti ir pasirodyti su keista mina tarp susibūrusių žmonių. Kita šalia yra senienų pardavėja, galinti parduoti už ịvairią kainą meilès viliones $[\ldots]{ }^{66}$

Sąmoningai apgaulę programavę maskaradai, vos atsiradę, taip pat susilaukė kritikos. Jie buvo smerkiami dvasininkų, pamfletistų ir publicistų, kurie manė, kad kaukių baliai sudaro grèsmę visuomenės moralei. Pasirodè daug raižinių, satyriškai vaizdavusių maskaradus kaip amoralią pramogą ${ }^{67}$. Kritinès pastabos maskaradų atžvilgiu siejosi su Jeano-Jacque’o Rousseau idejomis, kuriam miesto aprangos konvencijos, juolab persirengimai, buvo moralinės degradacijos ir natūralių visuomenès ryšių irimo simptomas ${ }^{68}$.

Grožinėje literatūroje ì kaukių balius žvelgta ambivalentiškai jie galëjo tapti ištvirkavimo ir laisvès, melo ir malonumo simboliais, nors paprastai maskaradai vis dèlto sieti su moralès klausimais ir tapatinti su ištvirkusių, malonumų siekiančių žmonių vaizdiniu ${ }^{69}$. Poetas ir publicistas Adomas Stanislovas Naruševičius (Adam Stanisław Naruszewicz) eilèraštyje „Reduty“ (Redutai) pasitelkè kaukių balių vaizdinị to meto visuomenès kritikai: redutu isigalejjimą jis siejo su visuotine veidmainyste, tapatybès slèpimu, pasirinktų vaidmenų apgaule ${ }^{70}$. Jo eilèraščio teksto kompozicija paremta analogija tarp redutu netvarkos bei Respublikos situacijos:

Pilna kaukių mieste, kad veikiausiai vos

Trečdalis [su jomis] nevaikšto kvailiojančioje Varšuvoje.

Kur tik eisi, nepažįstamas veidas; retas žmogus, kuris

66 [Wincenty Ignacy Marewicz], Proiekt nieuskuteczniony proza i wierszem Wincentego Ignacego Marewicza, Rotmistrza Woiewództwa Trockiego, w Warszawie, 1788, p. 42-51.

67 Aistringiausi kritikai žiūrèjo ị maskaradus kaip ị „kultūrinės epidemijos“ šaltinị, pvz., 1724 m. pamoksle Londono vyskupas sakè, kad maskaradai yra prancūzų sąmokslas, siekiantis pavergti tikrus britus, sejjant juose pasileidimą ir išlepimą. Žr. Terry Castle, op. cit., p. 2, 7.

68 Paweł T. Dobrowolski, op. cit., p. 72.

69 Terry Castle, op. cit., p. VIII.

70 Adam Naruszewicz, „Reduty“, in: Wiersze polityczne Pierwszego rozbioru i Sejmu delegacyjnego, p. 260-269. 
Kilminga kauke neprisidengtų,

Koks bebūtų luomas, prigimtis ir amžius,

Tampa nagingų rankų pagaminta figūra. ${ }^{71}$

Naruševičiaus eilėraštyje maskarado ,apverstas pasaulis“ atrodo ne kaip karnavalo linksmybės ypatybė, o kaip „apsivertusiu““, t. y. netikru žmonių pasaulis. Jame taip pat matome moralinès degradacijos metaforą:

\footnotetext{
Vargingumas prabangiuose auksaplaukiuose slepiasi,

Kvailiams baltos filosofų barzdos tịso,

Moterys sėdi ant žirgu, o vos ne kiekvienas vaikinas - tai boba:

Neturi drąsos, nei ištvermès, silpnos mintys ir rankos;

Senoliai persirengia nežabotais pantalonais,

Jaunikliai - arlekinas su lapių uodegomis,

Nosys - kaip vynuogès, pilvai - kaip trinkos.

Lengvabūdiškumas, ambicija, interesas amžiną puotą kelia -

Striksi lenkas ant vienos kojos, svetimas groja.

Ar pasaulis apsivertè, ar žmonės ant jo? ${ }^{72}$
}

\section{Kaukių baliai ir socialinè hierarchija}

Kaukių baliai, kaip jau buvo pastebèta, suteikè galimybę bendrauti skirtingu luomų žmonėms, kas paprastame gyvenime nebuvo sveikintina ir netgi baustina. Ypač žmonės iš aukštesnių sluoksnių baiminosi gėdos, kuri būtų užtraukta jiems ir jų šeimoms, būnant blogoje draugijoje $e^{73}$. Beje, Londono maskaraduose vakaro pabaigoje kaukès buvo nusiimamos, taip atskleidžiant tapatybę ir pabrěžiant ribą tarp luomų. Respublikos miestų maskaraduose tokios praktikos, berods, nebuvo.

Kitowiczius rašo, kad siekiant neatskleisti luominės tapatybės, $\mathfrak{i}$ redutus negalima buvo eiti su ginklu ir be kaukès, taip pat negalima buvo at-

71 Ibid., p. 260.

72 Ibid., p. 260-261.

73 Iškalbingą pavyzdị, kuriame matyti, kad vieši kontaktai su žemesnio luomo žmonėmis buvo laikomi gėdingais, pateikė Dobrowolskis, aprašęs, kaip viena Londono kilminga dama skundėsi moteriškam mėnraščiui, kad koncerte parke sutiko jauną, labai elegantiškai apsirengusią damą ir pamačiusi, kad ši blogai jaučiasi, užleidusi jai vietą, bet kai paaiškejjo, kad ši yra batsiuvio dukra, aukštuomenės dama patyrusi tokią gèdą, kad nebegalèsianti pasirodyti koncertuose visą sezoną. Žr. Paweł T. Dobrowolski, op. cit., p. 42-43. 
sivesti tarnų. Tiesa, aukščiausio rango asmenys kaukes galëjo nusiimti arba apskritai jų nedèvèti, o tik prisirišti prie rankos arba užkišti už skrybėlès:

nes kaukė buvo privaloma tik todèl, kad kompanijoje būtų lygybė, kad už vienodą sumą linksmintųsi be izžeidinėjimų ir garbės pamynimo. Žemos kilmès žmogus, jei nusiimdavo kaukę, pats save išstumdavo iš bendrijos su kilmingaisiais, bet kol buvo su kauke, niekas negalejo jo paniekinti ir jam pakenkti, net jei žinotų, kad tai nekilmingas žmogus <...> Batsiuvys, siuvejjas ir bet koks kitas amatininkas, prisidengęs kauke, linksminosi lygiai su ponais. Bet jei tik nusiimtų ją ir norètų su kuo kilmingesniu elgtis familiariai, tuoj pat sulauktų pasipriešinimo. ${ }^{74}$

Kitowiczius pastebi, kad kilmingieji taip pat vengdavo nusiimti kaukes, siekdami anonimiškumo, nes „nenorèjo būti atpažinti, kai vyras buvo sekamas žmonos ar meilužè meilužio“75. Anot jo, „tik tie, kas neturèjo priežasties slèptis ar sekti, po vieno ar dviejų salių apėjimų, nusiimdavo kaukes, kad galètų laisviau pakvėpuoti“"76.

Schulzas pastebėjo, kad Varšuvoje 10 deš. kaukių baliai pradèti rengti dviejose vietose, kurios skyrèsi bilietų kaina, taip pat aplinka ir besirenkančia publika: teatro salëje redutai buvo daug prabangesni, svečių kostiumai - kruopščiau parengti, šiuose baliuose mažiau šokta ir ieškota rafinuotesnių pramogų, o redutai Radvilų rūmuose vyko ne tokiose puošniose ir tvarkingose patalpose, bilieto kaina buvo pora auksinų mažesnè, o „kaukių laisvè didesnè“. I pastaruosius redutus žmonès ateidavo ir be kaukių, jei tik nenorėdavo slèptis, juose buvo daugiau šokama, nes tuo dažniausiai mėgavosi žemesnio sluoksnio žmonės ${ }^{77}$. Vilniuje, kaip buvo minėta, panašiu metu taip pat rengti „didieji“ ir „mažieji“ redutai, kurių bilietų kaina buvo skirtinga, tad veikiausiai ir publika galejo rinktis iš skirtingų sluoksnių.

İdomu, kad karininkas su kareiviais, kurie saugodavo redutų ramybę, turèjo užduotị atpažinti, kokia triukšmaujančio dalyvio luominè tapatybė ir elgtis su juo atitinkamai pagal spėjamą statusą:

74 Jędrzej Kitowicz, op. cit., p. 300-301.

75 Ibid., p. 301.

76 Ibid.

77 Fryderyk Schulz, op. cit., p. 184. 
Kas imdavo triukšmauti, iškart karininko ir kareivių būdavo išvedamas už durų, ten turèjo nusiimti kaukę. Karininkas spręsdavo apie asmenị ir savo nuožiūra su juo pasielgdavo (podtug swego rozsądku). Jei išvestas žmogus buvo pripažįstamas nekilmingu, liepdavo ji suimti ir nuvesti i areštinę arba išvanoti nugarą lazda. Jei triukšmadariai būdavo kilmingi žmonès, karininkas tik taip nubausdavo, kad daugiau nebeleisdavo ị redutus, o besivaidiję kitą dieną savo teises gynė įstatymu arba dvikova, šiuo antruoju būdu dažniau, kai kalba èjo apie negarbę arba kai buvo ịžeista moteris. ${ }^{78}$

Schulzas rašè, kad aukštuomenès narès visais atvejais maskavosi nuo galvos iki pėdų, ypač jei atvykdavo be vyrų, tačiau jis taip pat pastebėjo, kad moterų statusą galima buvo lengvai atpažinti pagal kostiumų skoningumą ${ }^{79}$.

Nofikow priskiria redutus prie ,visuomenės demokratizacijos įrankių “80. Iš tiesų XVIII a. antroje pusèje visuomenejje vyko poslinkiai distancijos tarp luomų mažėjimo linkme: to meto publicistikoje imta akcentuoti miestiečių luomo reikšmę kuriant visuotini gẻrị, idealizuota valstietija kaip esmingiausia, geriausia tautos dalis. Politiškai ir teisiškai luomų suartèjimas buvo įtvirtintas $1791 \mathrm{~m}$. gegužès $3 \mathrm{~d}$. konstitucijoje. Tuo metu plačiai manifestuotos „piliečių tautos“, apimančios visus ATR luomus, idejjos,

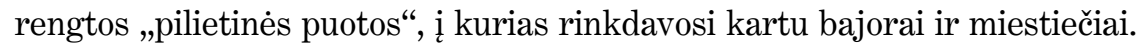
Tačiau netrukus Konstitucijos veikimas buvo nutrauktas, o luomų broliavimosi deklaracijos nesugriovè tų barjerų, kurie tuos luomus skyrè ${ }^{81}$. Reda Griškaitė pastebėjo, kad jau XIX a. Gabrielè Giunterytė-Puzinienė, kaukių baliuje išdrịsusi sušokti valsą su Rygos pirkliu Levenšteinu, sulaukè rimtu priekaištu. Nors moteris pusiau juokais, pusiau rimtai sake, kad nuo to ,jai neatsitiko nieko bloga“, vis dèlto buvo nevalia šokti su tuo, iš kurio dar tą patį rytą pirkai pirštinaites ${ }^{82}$.

Tačiau XVIII a. būta entuziastų, matančių kaukių baliuose priemonę ištaisyti visuomenès nelygybę. Poetas Koblańskis, demonstravęs „os-

78 Jędrzej Kitowicz, op. cit., p. 302.

79 Fryderyk Schulz, op. cit., p. 185.

80 Ewa Nofikow, op. cit., p. 92-93.

81 Pačiau apie tai žr. Lina Balaišytè, ,,Laimingos revoliucijos‘ šventès: apie Gegužès 3-iosios konstitucijos metines Lietuvos Didžiojoje Kunigaikštystėje“, in: Menotyra, 2017, Nr. 4, p. 260-273.

82 Reda Griškaitè, op. cit. 
tencinị demokratizmą“83, eilèraštyje „Oda na maski krakowskie“ pabrèžè demokratinị kaukių baliaus aspektą:

Užgavėnės atkeliavo, ị šoną visokie rūpesčiai!

Tas pats Bakchas yra liaudžiai, kaip ir jums, ponai.

İ šoną, dirbtuvès, palivarkai ir kaimai!

Pirmąkart matau visus luomus [drauge],

Vasaris laikinai grąžina lygybę,

Redutuose matyti, kad ir valstietis yra žmogus. ${ }^{84}$

Abejotina, kad valstiečiai iš tiesų dalyvaudavo redutuose, veikiau literatas turèjo omenyje visuotines linksmybes Užgavėnių metu. Luomų atskirtis, kaip jau minèta, buvo stipri, ir jos galèjo būti nepaisoma tik laikinai, o bandymai pereiti luomų ribas už baliaus ribų buvo traktuojami kaip grèsmè. Kitowiczius pažymi, kad Poznanėje redutai nebuvo gausūs, nes „ten bajorai nenorèjo broliautis su miestiečiais“" ${ }^{\text {(55 }}$.

Dobrowolskio nuomone, žaidimai su persirengimais vis dèlto tarnavo esamai tvarkai patvirtinti. Nors persirengus egzistuojančios ribos tarp skirtingų pasaulių atrodè nusitrynusios, bet amžininkų jos buvo preciziškai pažymètos ir gerai atpažistamos. Persirengimas prastuomenès rūbais, anot jo, turëjo papildomą prasmę - rodè, kad turtingieji žaidė varguomenę, dar labiau pažymėdami egzistuojančią ribą tarp šiu pasaulių ${ }^{86}$. Anot jo, suplanuota „kultūrinë“ apgavystė, koks buvo kaukių balius, igalino tapatybės patvirtinimą, bet nebuvo pasiūlymas sugriauti esamą sanklodą ${ }^{87}$. Galime sutikti su Dobrowolskio pastebėjimu, kad kaukių baliai buvo tarsi kontroliuojami (per bilietus) visuomenès saugumo vožtuvai, užtikrinantys miesto terpejje vidinę pusiausvyrą ir asimiliacijos mechanizmus ${ }^{88}$.

\section{Kaukių baliai ir politika}

Politiškai neramiais laikais, kai ATR patyrè dalies teritorijos praradimą pirmojo padalijimo metu ir virto kaimyninių šalių ittakos kovų are-

83 Janusz Ryba, Maskarady oświeconych, p. 77.

84 Józef Koblański, op. cit., p. 237.

85 Jędrzej Kitowicz, op. cit., p. 304.

86 Paweł T. Dobrowolski, op. cit., p. 74.

87 Ibid., p. 75.

88 Ibid., p. 77. 
na, kaukių baliais imta naudotis kaip vienu iš minkštosios galios ịrankių. Žinoma, kad Rusijos pasiuntinys Nikolajus Repninas Varšuvoje organizuodavo kaukių balius Jekaterinos II izžengimo ị sostą, caraičio Pavlo vardinių sukaktims paminèti ${ }^{89}$. Stanislovas Karolis Radvila surengè kaukių balių 3 tūkstančiams dalyvių Jekaterinos II gimtadienio proga ${ }^{90}$. Vilniuje redutai aktyviai rengti dislokuotos rusų kariuomenès karininkų. Šie renginiai itin tiko svetimos kariuomenès karininkijai, kuri stengèsi įtraukti kuo platesnius vietinių gyventojų sluoksnius ị Rusijos valdovams skirtas šventes. Pavyzdžiui, 1773 m. rusų generolas Stepanas Rževskis Vilniuje surengė Rusijos imperatorės karūnavimo metinèms šventę, kuri buvo užbaigta kaukių baliumi Oginskių rūmuose. I jị buvo sukviesta 380 porų. Siekiant pabrèžti rusų karininko nuopelnus miesto bendruomenei, laikraštis paminėjo, kad bilietai i ši kaukių balių buvo išdalyti nemokamai, kad „buvo pasamdytos 3 kapelos, gèrimai ir visa ịranga, rūmų puošyba ir iliuminacija surengta p. Generolo lëšomis, o šventè prižiūrima kareivių “"91.

Po pirmojo valstybės padalijimo rusų karininkai, siekdami užsitikrinti miesto gyventojų palankumą, èmėsi rengti maskaradus reguliariai. Grèsmingos svetimos jègos išgąsdintoje visuomenėje laikraščio pranešèjas apie šiuos renginius rašè itin nuolankiu tonu:

\footnotetext{
Visų luomų ir padėties vietiniai gyventojai, išgyvenę įvairius sunkumus, tapus komendantu Rusijos kariuomenès pulkininkui Zaborovskiui patiria malonią ramybę $<\ldots>$ Jis, pamynęs savo interesus, gyventojams pageidaujant užleido Vilniaus kaštelionų [Oginskių] rūmus, kad ten iki šiol vargę miestiečiai turètų pramogas ir kad visiems būtų suteikta galimybė du kartus per savaitę vykstančiuose, sargybos prižiūrimuose redutuose saugiai pramogauti. ${ }^{92}$
}

Nežinoma, kiek ilgai rusų kariuomenės komendanto buvo rengiami reguliarūs kaukių baliai. Veikiausiai tiek, kiek buvo aktualu politiškai. Kaip buvo rašyta, jau 1780 m. išskirtinę redutu rengimo teisę gavo valdovo patikètinis Ryxas.

89 Apie tai plačiau žr. Lina Balaišytè, „Rusų karininkija kasdieniniame ir šventiniame XVIII a. Vilniaus gyvenime: taikaus sugyvenimo regimybe்“, in: XVIII amžiaus studijos, t. 4: Lietuvos Didžioji Kunigaikštystè. Visuomenè. Kasdienybès istorija, sud. R. Šmigelskytè-Stukienè, Vilnius: Lietuvos istorijos institutas, 2018, p. 229-243.

90 Janusz Ryba, Maskarady oświeconych, p. 22.

91 Gazety Wileńskie, 1773, Nr. XLI.

92 Gazety Wileńskie, 1773, Nr. III. 
Kaukių baliai taip pat rengti siekiant užmegzti glaudesnị ryšį tarp rusų karininkų ir vietinės aukštuomenès, pavyzdžiui, ị Vilnių atvykus Vilniaus vaivadai Karoliui Stanislovui Radvilai, rusų pulkininkas Ivanas Ferzonas (Ferzenas) LDK raštininkienès Teresės Barboros Radvilaitès-Pacienės rūmuose „surengė kaukių balių su prabangiai ir meistriškai patiekta vakariene, skirta 140 asmenu “93.

Tuo metu literatūroje kaukių baliai tapo diskusijos apie patriotizmą ir santykị su svetimu tema. Kritiniai kūriniai smerkè pasilinksminimus sunkiu tèvynei metu. $1774 \mathrm{~m}$. publikuotas anoniminis eilèraštis „Na maszkaradę niewolników“ (Belaisvių / vergų maskarade) buvo skirtas Varšuvoje vykusiems redutams, kuriuose keliolika dalyvių pasirodė sukaustyti grandinėmis, vaizduodami belaisvius ar vergus. Satyrinio eilèraščio autorius kaltino besilinksminančius maskarade, kad tokiu būdu jie įteisina svetimụjų galybių primestą padètị:

Lenkija nelaisvèje visą Europą stebina,

O lenkai su savo likimu taip susigyveno,

Kad džiaugsmu ir linksmybe prievartą pateisina,

İkalindama grandinėmis ir tuos, kurie neužsitarnavo. ${ }^{94}$

Satyros autorius pabrèžia ir moterų atsakomybę už situaciją valstybëje:

O jūs, dailios merginos, kurios širdis

Taip galite valdyti saldžia galia,

Kodèl jūs ne romietès ir ne spartietès

Esate, jeigu savo tėvynès negandas matote,

Jūsų galioje mintị iškelti, viltị suteikti,

Kamilus ir Scipijonus, Regulus pagimdyti.

Ne niekšinga prabanga turètų jums rūpèti.

Tegu užsitarnauja lenkai savas linksmybes..$^{95}$

93 Gazety Wileńskie, 1778, Nr. XXV.

94 „Na maszkaradę niewolników“, in: Wiersze polityczne Pierwszego rozbioru i Sejmu delegacyjnego, p. 240.

95 Ibid. 
Satyra tuoj pat susilaukė atsako, ir anonimas parašė atsakymą moters vardu „Odpowiedź jednej damy w maszkaradzie niewolników będącej“(Vienos damos, buvusios vergų maskarade, atsakymas):

Deja, paskutinis išsigelbëjimas tėvynei,

Kai jos apgynimui tik moterų balsas

Turi įkvèpti vyrus ir būti vedliu

I garbę, kad nebūtų niekingu vergu. ${ }^{96}$

Nofikow spejja, kad atsakymas buvo sukurtas valdovui artimos diduomenės aplinkoje ${ }^{97}$. Valdovo proteguojamuose leidiniuose, kaip laikraštyje Monitor, tokio pobūdžio pasilinksminimai buvo remiami ${ }^{98}$. Atsakomajame eilèraštyje kaukių balius traktuojamas kaip nekenksminga pramoga net ir kritinèje kraštui situacijoje:

Ietis, ị tẻvynès krūtinę baisiai įsmeigta,

vien tik gedulu nebus ištraukta.

Ištraukus ją iš svetimujų rankų, skausmą jos apmalšins,

Gailestis jos neišgydys, pramoga nepakenks. <...>

Kadangi mūsų grandinès, dèl nekaltos pramogos

Uždètos, sukèlė piktą pajuoką,

Tad jei norite iš mūsų imti pavyzdį, prašome:

Mes grandines nusimetème, o jūs iki šiol nešiojate. ${ }^{99}$

Nofikow rašo, kad visuomenëje didesnio dèmesio sulaukè ne pats kaukių balius, bet satyra, smerkianti pramogos dalyvių sumanymą. İdomu, kad satyra pasirodė paties „belaisvių“ baliaus metu: salëje pasirodė domino vilkinti figūra ir išdalijo dovanèles, kuriose vietoj saldumynų buvo įvyniotas eilèraštis ${ }^{100}$. Elżbieta Aleksandrowska, tyrusi išdavystės sampratą, pažymi,

96 „Odpowiedź jednej damy w maszkaradzie niewolników będącej“, in: Wiersze polityczne Pierwszego rozbioru i Sejmu delegacyjnego, p. 243.

97 Ewa Nofikow, op. cit., p. 124.

98 Elżbieta Aleksandrowska, „Problem zrady na podstawie Satyr i pamfletow na Polki balujące w czasach tragicznych dla ojczyzny (1774-1832)“, in: Bo insza jest rzecz zdradzić, insza dać się zludzić. Problem zdrady w Polsce przelomu XVIII $i$ XIX w., praca zbiorowa pod redakcją Anny Grześkowiak-Krwawić, Warszawa: Instytut Badań Literackich, 1995, p. 119.

99 „Odpowiedź jednej damy w maszkaradzie niewolników będącej“, p. 243-244.

100 Ewa Nofikow, op. cit., p. 118-120. 
kad vergų kaukių sumanytojo intencija veikiausiai taip pat buvo satyrinė ir vergų kaukės turèjo pasitarnauti „tautos išblaivinimui““101.

Apibendrindami galime dar kartą pažymèti, kad vieši kaukių baliai buvo išskirtinis XVIII a. reiškinys. Jie tapo miesto renginiais, kurie linksmybes, prisidengus kauke, perkẻlè iš hermetiškos dvarų aplinkos ir liaudiškų gatvės švenčių i uždarą ir kontroliuojamą erdvę. Bilietų pirkimas suteikẻ renginiui išskirtinumo regimybę, nors iš tiesų kaukių baliai XVIII a. antroje pusejje tapo prieinami beveik visiems miesto gyventojų sluoksniams. Pamažu šių renginių vietų miestuose daugejjo ir jie „išsisluoksniavo“, prisiderindami prie skirtingų žmonių grupių finansinių galimybių ir poreikių. Kaukių baliai kūrė visuomenės lygybės iliuziją, kadangi užsimaskavusio žmogaus luominė tapatybė buvo nežinoma ir jam nebuvo leidžiama turèti visuomeninị statusą liudijančių atributų (ginklo, tarnų). Tačiau lygybė kaukių baliuose buvo efemeriška - žmogaus statusas dažniausiai buvo atpažistamas, o aukštuomenès nariụ neretai net neslepiamas. Šių balių apsauga galėjo, vadovaudamasi sveika nuovoka, atpažinti renginyje sulaikyto už nusižengimus žmogaus luomą ir atitinkamai ji bausti. Nors redutu paplitimas tam tikru mastu galëjo rodyti visuomenės demokratizacijos, luominių barjerų mažejimo procesus, tačiau socialinės ribos išliko aiškiai nužymètos ir visiems suprantamos. Maskaradų patrauklumą pirmiausia kūrẻ anonimiškumo galimybė, kuri leido elgtis nevaržomai. Maskaraduose buvo realizuojamas polinkis kurti iliuziją ir apgaulę, kurios vieniems buvo kontroliuojamo visuomeninio žaidimo elementas, kitiems - būdas užsimaskuoti, slepiant savo socialinę padètį.

Gauta 20200323 
Šaltiniai

Gazety Wileńskie, 1773, Nr. III, XLI; 1778, Nr. XXV.

Griškaitė Reda, „Šokantis Vilnius“, atiduotas spaudai, in: Pasakojimai apie Vilniu ir vilniečius III, Vilnius: Lietuvos istorijos institutas, 2020.

Kitowicz Jędziej, Opis obyczajów za panowania Augusta III, Warszawa: Państwowy Instytut Wydawniczy, 1999.

Koblański Józef, „Oda na maski krakowskie w karnawał 1774 w bandzie J. W. Humieneckiej, miecznikowej koronnej“; „Na maszkaradę niewolników“; „Odpowiedź jednej damy w maszkaradzie niewolników będącej“; Naruszewicz Adam, „Reduty“, in: Wiersze polityczne Pierwszego rozbioru i Sejmu delegacyjnego, 1772-17\%5, opracowała Barbara Wolska, Warszawa: Wydawnictwo Sejmowe, 2001.

[Marewicz Wincenty Ignacy], Proiekt nieuskuteczniony proza i wierszem Wincentego Ignacego Marewicza, Rotmistrza Woiewództwa Trockiego, w Warszawie, 1788.

Schulz Fryderyk, Podróże Inflantczyka z Rygi do Warszawy $i$ po Polsce w latach 1791-1793, Warszawa: Spółdzielnia Wydawnicza Czytelnik, 1956.

Węgierski Kajetan Tomasz, „Ostatni Wtorek“, [interaktyvus], [žiūrèta 2019-10-25], https://pl.wikisource.org/wiki/Poezye Tomasza_Kajetana_W\%C4\%99gierskiego/ Ostatni_Wtorek.

\section{Literatūra}

Aleksandrowska Elżbieta, „Problem zrady na podstawie Satyr i pamfletow na Polki balujące w czasach tragicznych dla ojczyzny (1774-1832)“, in: Bo insza jest rzecz zdradzić, insza dać się zludzić. Problem zdrady $w$ Polsce przelomu XVIII $i$ XIX $w$, praca zbiorowa pod redakcją Anny Grześkowiak-Krwawić, Warszawa: Instytut Badań Literackich, 1995, p. 115-131.
Balaišytė Lina, „„Laimingos revoliucijos‘ šventès: apie Gegužès 3-iosios konstitucijos metines Lietuvos Didžiojoje Kunigaikštystèje“, in: Menotyra, 2017, Nr. 4, p. 260-273.

Balaišytė Lina, „Rusų karininkija kasdieniniame ir šventiniame XVIII a. Vilniaus gyvenime: taikaus sugyvenimo regimybe்“, in: XVIII amžiaus studijos, t. 4: Lietuvos Didžioji Kunigaikštystè. Visuomene. Kasdienybès istorija, sud. R. Šmigelskytè-Stukienè, Vilnius: Lietuvos istorijos institutas, 2018, p. 229-243.

Bernatowicz Aleksandra, Malarze $w$ Warszawie czasów Stanistawa Augusta. Status, aspiracje, twórczość, Warszawa: Instytut Sztuki PAN, 2016.

Brusokas Eduardas, Glemža Liudas, „Vilniaus savivaldos struktūra ir organizacija po ketverių metų seimo miestų reformos (1792, 1794 m.)“, in: Lietuvos istorijos metraštis, 2008, t. 1, 2009, p. 45-72.

Burba Domininkas, „Bajoru gyvenimo peripetijos XVIII a. vidurio Lietuvos Didžiosios Kunigaikštystès sostinėje pagal Vilniaus kanauninko Jono Dominyko Lopacinskio asmeninę korespondenciją“, in: Istorija, 2015, t. 97, Nr. 1, p. 26-46.

Castle Terry, Masquerade and civilization: the carnivalesque in eighteenth-century English culture and fiction, Stanford: Stanford University Press, 1986.

Ciesielski Tomasz, „Zapusty szlacheckie i magnackie w XVIII wieku w świetle Opisu obyczajów za panowania Augusta III Jędzieja Kitowicza oraz pamiętników i dzienników z czasów saskich“, in: Memuarystyka $w$ dawnej Polsce, redakcja Piotr Borek, Dariusz Chemperek, Anna Nowicka-Struska, Kraków: Collegium Columbinum, 2016, p. 203-217.

Dobrowolski Paweł T., Poszukiwanie tożsamości: cztery studia o angielskim Oświeceniu, Warszawa: Collegium Civitas Press, 2015.

Glemža Liudas, „Vilniaus pramogos: maskaradai“, [interaktyvus], [žiūrèta 2019-04-30], http://m.ldkistorija.lt/index.php/istori- 
niai-faktai/pramogos-vilniuje-maskaradai/1326.

Nofikow Ewa, Polski karnawat: obrazy obyczajów świątecznych w piśmiennictwie trzech stuleci: od XVII do XIX wieku, Białystok: Wydawnictwo Uniwersytetu w Białymstoku, 2015.

Ryba Janusz, Maskarady oświeconych. Próba opisu zjawiska, Katowice: Wydawnictwo Uniwersytetu Śląskiego, 1998.

Ryba Janusz, Oświeceniowe tutti frutti. Maskarady-konwersacja-literatura, Katowice: Wydawnictwo Uniwersytetu Śląskiego, 2009.

Wierzbicka-Michalska Karyna, Michalski Jerzy, „Ryx Franciszek“, in: Polski Stownik Biograficzny, Wrocław, Warszawa, Kraków: Zakład Narodowy Imienia Ossolińskich, Wydawnictwo PAN, 1991-1992, t. 33, p. 597-601. 


\title{
Summary
}

\section{Masquerades and the $18^{\text {th }}$ Century Society}

\author{
Lina Balaišytè
}

Keywords: $18^{\text {th }}$ century society; masquerades; social classes.

The paper offers an enquiry into masquerades as a social phenomenon. The peculiarity of masquerades-public events that emerged and were popularised in the 18th century-is that they provided different social classes with a unique opportunity to have fun together. The paper aims to research the structure of the 18th century society and identify the social changes that fuelled the demand to transcend the limits between social classes through this particular form of entertainment. By drawing on memoirs, fiction, and press reports, the paper analyses the function and social reception of masquerades. Even though the popularity of masquerades could be regarded as a sign of democratisation and diminishing of class barriers in society, these barriers remained very much present and obvious to everybody. Because the identities of people behind masks were unknown and participants were not permitted to bring any status-related attributes (such as weapons or servants), masquerades were creating an illusion of social equality. Yet this equality was rather ephemeral — the person's status was still often recognisable nonetheless and the aristocracy was not even attempting to hide it. The masquerade security forces were allowed to use their judgment and punish the wrongdoers according to their class. It is worth noting that, as masquerades were gradually gaining popularity, they were also subjected to "stratification": they adapted to the financial situations and demands of various social groups and, while becoming accessible to the poor, masquerades also introduced even greater social divisions. Masquerades were attractive primarily due to the unrestricted exploration of the possibilities of anonymity. They were based on the natural tendency to create illusions and tricks, which some saw as part of a controlled social 
game, while others saw them as a chance to hide their social status. The paper also concludes that, due to the mass character and the capacity to draw crowds from all social strata, masquerades were also used as tools of soft power: for example, in Vilnius, masquerades used to be organised by the officers of the Russian army deployed in the city at that time. This also served as a reason for debates about patriotism and treason. 